\title{
Piety, Practices of Reading, and Inquisition. A Catalan Saint Cyprian Prayer from 1557 and Its Context ${ }^{1}$
}

\author{
Bernadett Smid \\ Senior Lecturer, Eötvös Loránd University, Faculty of Humanities, \\ Institute of Ethnography and Folklore, Department of Folklore, Hungary
}

\begin{abstract}
The author of this article focuses on a defendant of an Inquisition trial (1641-1644) and its sources, namely a healing hermit and the Saint Cyprian prayer, published in Catalan in 1557 and used by the hermit as a verbal charm. Beyond the philological and folkloristic study of the prayer text, this paper presents the vulgarisation of reading skills and the realization of reading practice in a specific social context in the Principality of Catalonia. The author uses the most important and relevant theological literature of the period and the attestations of the trial as keys of reading. She pays special attention to the context of prayer and its actual social use. Her aim is to analyse the textual elements and gestures of the healing rite; hence, she investigates the probable readings of the healing specialist, which makes possible to reach a deeper understanding of the hermit's role as a cultural mediator.
\end{abstract}

Keywords: popular healing, charm, prayer of Saint Cyprian, reading practices, Catalan popular culture, $17^{\text {th }}$ century, Inquisition, Solsona

"Reading is always a practice embodied in gestures, spaces, and habits."

(CHARTIER 1992:51)

\section{INTRODUCTION}

Researchers of the history of reading have drawn attention to the fact that prints and chapbook publications found their way into the life of the "people" in many ways. Some of the authors treat this kind of "popular" literature as literary sources and call for a thematic

1 This paper and project were supported by the János Bolyai Research Scholarship of the Hungarian Academy of Sciences, and is preliminary to a longer work of the author on religious life and magical practices in the Early Modern period. 
content analysis, while others suggest a more thorough examination of the sociocultural context of the authors and users. But whose view of the world is represented in the sources analysed by the studies? Natalie Zemon Davis mentions in her summarising work that due to the lack of direct data, it is difficult to assess how village readers received, for example, the stories of the books with a blue cover (Bibliothèque bleue). ${ }^{2}$

Printing is more than technological determinism, as it has created new communication networks and provided new choices as well as new tools for the creators and distributors of texts (DAVIS 2001:169). Literacy and the spread of printed religious texts in vulgar languages enabled, among other things, vernacular forms of the practice of piety for the wider public. Paradoxically, at the same time, this meant a significant loss of control for the Catholic Church in the Early Modern era, since it carried the possibility of multiple ways of reading and interpretation. In the words of Michel de Certeau, we may think of reading not as a passive activity but as a creative practice (lectio) during which the reader strolls within a ready-made system, just like in the built structure of a city or a shopping centre (DE CERTEAU 2000:181). ${ }^{3}$ In light of this approach, every single reading changes its own object, too. Being a structure of signs, written text offers the reader the opportunity to attach meaning to it, and in this sense, the text is the construction of the active reader(s). This allows for the creation of another, new meaning in the course of reading, which is different from the original purpose of the author. Readers separate the text from its origins and reorganise its various textual elements and parts: they meander in the text and attribute a different meaning to the sentences. Furthermore, despite being in the territories of the author, they use their own tactics and tricks during the game (DE CERTEAU 2000:182). According to this theory, reading is a sort of "poaching", since it creates a different interpretation besides the only orthodox and legitimised one created and authorised by the author, the publisher, or, occasionally, the commentator. Therefore, reading is also interpretation; if we accept that we also need to realise during examining texts that the typical texts of a given era are connected to the ways they were used and read in different ways, that is, in their (sometimes changing) context. Natalie Zemon Davis also emphasises that the researcher should extend the thematic analysis of texts with data related to the readers (audiences) of the book and the recommended, imagined, or ideal receivers (publics): instead of treating the printed book merely as a source of thoughts and images, seeing it also as a carrier of relations (DAvIs 2001:171). ${ }^{4}$

2 The term blue library refers to a type of ephemera and popular literature published in Early Modern France between c. 1602 and c. 1830, comparable to the English chapbook and the German Volksbuch.

3 Natalie Zemon Davis uses a similar metaphor: "When a peasant read or was read to, it was not the stamping of a literal message on blank sheet; it was the varied motion of a 'strange top' (to use JeanPaul Sartre's metaphor for the literary object) set to turning only by the combined effort of author and reader." See DAVIS 1981:71

4 The author sees complementary data enabling the use of this method apart from small details on the pages of the original publications, for example, in studies on literacy and dialects, accounts and notes about ownership, price, authorship, and the publishers' principles related to the books, as well as sources on the habits and social life of peasants and artisans. Ab the authors who developed the method, see Davis 2001:171, and a few French examples on page 169. Hereby, these are not discussed in further detail. 
In his works on the culture of reading, the French cultural historian Roger Chartier draws attention to the diversity of characters, temperaments, various abilities, age, and expectations on the one hand (CHARTIER 2011b:162), and the reading practice of different social groups on the other (see, for example, CHARTIER 2011a:335). He introduces the latter thought in connection with La Celestina, a popular "tragicomedy" by the Spanish Fernando de Rojas first published in 1499, also observing how certain ways of use truncate a work of art and deprive it of its real meaning (CHARTIER 2011b:163). As aforesaid, it seems reasonable to examine a written text in a complex way, including its materiality, material form, textual quality, and orally realised character - the social implications of reading beyond the text itself. For instance, the significance of social reading and the consequent social effect of the text are both to be examined. Besides quantitative data, we have a remarkably low number of examples that would help us see the impact of reading on individuals, their view of the world, or their closer or wider environment. These sources provide the researcher an insight into the inner world and social environment of the users of the texts. The work of microhistorian Carlo Ginzburg has been a unique and much-quoted example in the field of "popular" reading for decades. The author examined the Inquisition trial of a heterodox miller in the Middle Ages, from which we learn how the readings of Menocchio - a miller from Friuli - shaped his view of the world. His case derives from two great events: the invention of printing and Reformation. According to Ginzburg, the case of this miller provides an example of how the monopoly of scientists in the field of literary culture came to an end (GINZBURG 1992:XXIV).

Menocchio as a "popular reader" was unique not because of the few readings he knew, but because of a peculiar way of reading and interpretation with which he enlisted the texts he came upon in the service of a popular cosmogony with a special colouring (CHARTIER 2011:337). ${ }^{5}$ His thinking and his view of the world is known from testimonies in Inquisition trials. From these, it turns out that certain elements of his views were welcomed by his close community as well. His reading practice became important because of its proven social dimension - and not because of its peculiar character - and the main problem for the church was how the miller of Friuli as a reader interpreted his readings, and how much he deviated from the official church dogmas. Although the aim of the publishers and authors with the orthodox texts was to serve the intensification of religious beliefs, the publications allowed for alternate, popular readings, thus becoming suitable for "poaching". Scientists of the history of reading have emphasised the significance of the exploration and interpretation of reader communities beyond the texts themselves based on similar phenomena: these communities used the texts with a special interpretation, alongside various practices and reception strategies (see PÉREZ GARCÍA 2002:251). Through all of the above, the author wishes to highlight the necessity of exploring the social horizon in the historical study of reading - beyond the textual aspects, the examination of the interpreting individuals and communities and their special reading practice. As it can be seen in the example of Menocchio, the fortunate researcher may gain access to these practices through qualitative data of Inquisition trials.

5 The Cheese and the Worms was first published in 1976 in Italian; the English translation in 1980, and the Hungarian in 1991. 
The aim of the present study is to explore how and in what intellectual, social, material, and gestural context a specific prayer published in the form of a printed "small booklet" (mentioned in the trial as librito, i.e., small book) was used by a certain healing specialist from Spain (León) named Hiacinto (Jacinto) García in Solsona, a rural town in the $17^{\text {th }}$-century Principality of Catalonia. After having published the Catalan print from 1557 and having analyzed its content, the study attempts to contextualise the text based on the reading and healing practices, unique ritual text use, gestures, and personal textual microcosm of the healing specialist. The text of the prayer, published two years before its official ban by the Catholic church, survived in the documentation of an Inquisition trial taking place between 1641 and 1644 as a piece of material evidence brought in against the defendant. ${ }^{6}$ The Holy Inquisition started a procedure against the hermit because of the use of the superstitious prayer itself, which has survived thanks to that legal case. Some of the questions raised by the study are related to the world of the text, while others deal with the ways of use and reading. In deciphering the latter, the testimonies of the trial are used as the main source. This could help to understand how and with what purpose this hermit used the prayer of Saint Cyprian in a town community, what kind of common system of notions authorised him to do that, and in the frame of what ritual momenta he put the text into operation - considering the statement of Chartier introduced above: the meaning of a text is also affected by the ways people read it (CHARTIER 2011a:342). Furthermore, the study aims not to talk about "the people" in general, but, as far as the data of the sources allow, to present social or interest groups consisting of identifiable individuals connected to each other. For this purpose, the testimonies of the Inquisition trial and other complementary Catalan, Spanish, and Latin sources are used. The final part of the present work may also be called a case study. However, before moving on to the contextual examination, it is important to introduce the debates related to the ancient prayer based on ecclesiastic sources in Spanish from the Early Modern times, as well as to present cultural historical facts related to Cyprian, the decanonised saint of the prayer, and to raise some related questions. ${ }^{7}$

The wider context of the study is seen in a common European process in which the church aimed to "purify" certain medieval practices and related concepts, such as prayer, benediction, and exorcism. This aspiration gained an even greater momentum after the Council of Trent, ${ }^{8}$ while it resulted in the need for drawing the boundary between religion and non-religion (magic and science).

${ }_{6}$ Arxiu Històric de la Ciutat de Barcelona (AHCB) 16/1C. XVIII-9. Processo de fe contra el ermitaño de San Bartholomé del termino de la ciudad de Solsona, Fra Hiacinto García (Religious trial against father Hiacinto García, the hermit of Saint Bartholomew hermitage near the town of Solsona)

7 The author would like to hereby express her utmost gratitude to the members of the East-West Research Group of the Hungarian Academy of Sciences, especially to Éva Pócs, Judit Kis-Halas, Gábor Klaniczay, and Dániel Bárth, for the ways they helped and promoted her work with their professional advice, comments, and insights during several meetings and conferences.

8 The process includes several subtopics, only a few of which are mentioned in the footnotes, in order to touch upon the international interpretation of the topic. One of the closely related subtopics, as it becomes obvious in connection with the prayer mentioned, is exorcism, which has been discussed more frequently in the past few years, primarily in the context of cultural history. Studies by Moshe Sluhovsky proved that obsession was one of the most important hermeneutical issues for the church between 1400 and 1700. Exorcism, which had been an unregulated and trivial procedure in the Middle 


\section{DIFFERENT READING PRACTICES: THE PRAYER IN EARLY MODERN SPAIN}

Below, related to the topic of the study, this study presents examples for the use of prayers and prayer texts themselves from the Iberian Peninsula of Early Modern times, after which a specific type of prayer, Saint Cyprian's prayer is introduced. The Catholic Church started to draw attention to the "mistaken" and "wrong" nature of the prayer in the period discussed. At the time, the texts meant for religious use, serving to enhance devotion, was a peculiar problem on the Iberian Peninsula, both in terms of content and social aspect. Clerical works in demonology and theology prove that serious heretical offence could occur with the use of religious texts, whether in manuscript or print (PEÑA DíAz 2015:79). Their popularity and relentless utilisation may be explained by their function for the new and old Catholic communities. Whether read out, said, performed ritually, or worn on the body, the texts could enhance individual protection from illnesses, or keep away any other physical or psychological problem, as well as individual or community crisis. The church started to put a strict ban on these and similar practices, regarded as sinful, on the Iberian Peninsula in the middle of the $16^{\text {th }}$ century. One of the most influential representatives of the church prohibitions was the Spanish mathematician-theologian Pedro Ciruelo (1470-1548). His treatise, Reprobación de las supersticiones y hechizerias (Reprobation of all superstition and witchcraft) ${ }^{9}$, first published in 1530 in Salamanca, was printed eight times between 1538 and 1628, and already the first edition gained a reputation beyond the local. ${ }^{10}$ In this work, the author presents and denounces various magical and "superstitious" practices. Among them, he mentions not only oral practices but also ones

Ages, became a liturgical action controlled by the church. The change involved the modification of the exorcist's role: from a health specialist, this person became the explorer and decipherer of inner psychological processes. In the practice of exorcism, Sluhovsky sees nothing elt a linguistic construct that interprets the spiritual process and the related physical-somatic symptoms together, examining the process in a hermeneutical framework (SLuHovsKy 2007:1-2). Let us also consider a quote from another author, Keith Thomas, who examined the period between 1500 and 1700 in England. His central question is what caused the decline of the belief in magic in the mentioned period. Chapter 5, on prayer and prophecy, is closely related to the topic, such as the part dedicated to the topic of magic (magical healing, specialists, and the relationship between popular magic and religion). See Thomas 1991:133-178, and 209-332. Stuart Clark also treats the relations of the church and magic with a special focus when presenting the history of Early Modern witchcraft (see Clark 1997:458-459). The list could go on; however, the aim of the present study is to outline a broader European context instead of giving an overview of science history.

9 The English translation of the work of Ciruelo appeared in 1977 with this title: A treatise reproving all superstitions and forms of witchcraft.

10 Ciruelo 1538. This is not the date mentioned in the Bibliography, The convert theologianmathematician was born in Daroca, Aragon (Spain). He started his studies in Zaragoza and moved to Salamanca around 1482 to learn the seven liberal arts from the famous university professors. In 1492, he travelled to Paris, where he studied theology and taught mathematics for more than 10 years. After he returned to Spain, he gave lectures on Thomist philosophy at the University of Alcalá de Henares, which had been founded recently. In 1514, he published a manual meant for priests with the title Arte de bien confesar (The Art of Confessing Well). It was published 22 times until 1560, which shows how much more popular it was than similar works of other contemporary authors on the topic. Besides his works about witcheraft and superstition, he published ten further works in theology and philosophy, and he was the first to publish a mathematics coursebook in Spain. He also translated texts from Hebrew to Latin (TAUSIET 2004:191-192). 
related to literacy - for example, the massive use of healing cards, which was widespread in a geographical sense as well. ${ }^{11}$ Contemporary sources from the whole territory of the Iberian Peninsula prove that, in parallel with the vulgarisation of reading and writing, certain new practices emerged that opened a door to modern solutions and communicative forms as yet unknown in the ancient field of magic (MARQUILHAS 1999:125).

The question of right and wrong prayer texts appeared in the discussion of "superstitious" wrong deeds in demonological works. The importance of the redefinition, "purification" and control of prayers is further proven by the lists of banned Early Modern books: the indexes. These publications name a dozen prayers that are considered by the Catholic Church from Spain, Portugal, and Rome and by the Inquisition as non-desirable or to be "expurgated" and corrected. The indexes published after one another notoriously list the same prayers, calling for their ban or modification. Currently, the text of six types of "popular" prayers is known. All of them were written in vernacular languages, and some were circulated also in books of hours. These texts only contained theological mistakes in terms of content, not structure. ${ }^{12}$ The ban of the church on the prayers was probably encouraged by the magical purposes detailed in the instructions for using the texts, as well as by the popular practices related to chanting the prayers of various saints.

Hereby, the study overviews how contemporary sources describe a prayer classified as dangerous, one to be banned or at least corrected. To answer that question, excerpts from the Confessionario by Pedro Ciruelo - the above-mentioned instructions on confessing and hearing confessions - will be presented. ${ }^{13}$ Ciruelo attaches the label of superstition and idolatry to those "futile ceremonies" which "vain ceremonies that many simple people perform for the sake of indiscreet devotion, although seeming saint and good,

11 The peremptory treatise of Ciruelo was published a year after Franciscan friar Martín de Castañega's work, titled Tratado muy sotil y bien fundado de las supersticiones y hechizerias y vanos conjuros $y$ abussiones, y otras cosas al caso tocantes, $y$ de la possibilidad y remedio dellas (Detailed and thorough treatise about various superstitions, charms, futile conjurations and machinations and other such things as well as their remedy about superstitions, witchcraft and vain spells as well as machinations, along with other related things and the possibility and remedy of them" is the literal translation from Spanish). Both authors wrote their treatises with a similar purpose: to provide a didactic argumentation on what is prohibited and what is allowed in magical and superstitious activities. Their sources were also similar: they used the Bible, as well as the writings of Saint Augustine, Saint Isidor of Seville, Saint Thomas Aquinas, and Jean Gerson, the rector of the University of Paris, whose work denouncing superstitions had been published earlier. Both Ciruelo and Castañega regard flying and shapeshifting of witches as the deeds of the demon, and, as in the spirit of reform, they both condemn the use of various charms in healing practice, including priests. However, the work of the Franciscan friar had been soon forgotten, while Ciruelo's treatise served as a foundation of the dominant clerical reform discourse of the Spanish and Catalan areas in the $16^{\text {th }}-17^{\text {th }}$ centuries. In Solsona, the town exe present study examines, it was published again in 1628 with a new, updated foreword, and it continued to serve as a primary source of reference throughout the $17^{\text {th }}$ century (Ciruelo 1628). However, in the course of the $17^{\text {th }}$ century on the Peninsula, the role of Ciruelo's treatise was gradually passed on to the work of Martín Del Río, Disquisitiones Magicae libri sex (Six Books on Disquisitions about Magic), published in 1599-1600 (TAUSIET 2004:192). For more details about the two authors, see TAUSIET 1994.

12 Further on the topic, see the doctoral work of Londoño Marcela, which overviews indexes listing $16^{\text {th }}$ - century books prohibited by the church and discusses prayers appearing in the books (LONDOÑO 2014).

13 Ciruelo 1544. (The first edition was published in Alcalá in 1524.) 
however, when said with such purposes, they are vain and evil". ${ }^{14}$ In order to confine the use of these prayers, Ciruelo recommends the confessors to ask the believers whether they know prayers "that have to be said on specific days and at certain hours, repeated a certain number of times". The confessors are aided in recognising these prayers by the fact that they promise that in case one keeps to the ceremonies as described, they shall be rewarded with special favours by God..$^{15}$ The author of the confession instructions details the nature of the mentioned "futile ceremonies" as well. For example, during these, believers use candles. The joint purpose of saying the texts and the connected ritual elements is for the believers to secretly receive some kind of grace or reward. The most important problem, according to Ciruelo, stems from the fact that all that is realised with the help of the devil, not of God.

The other reprehensible practice mentioned by Ciruelo is the technique of ars notoria that was widely known in the Middle Ages, relevant here as it occasionally also included prayer texts. Preparation is needed before using these practices: the magician, after having gone through fasting and periods spent in silence for physical and spiritual purification, says a series of prayers for several weeks, while he calls the angels to help him acquire certain abilities. These texts originally served a more efficient memory, rhetorical skills, and the fast acquisition of the Seven Liberal Arts, i.e., medieval sciences, therefore one may assume a group of university students and lecturers behind them (LÁNG 2007:48-49). Other similar texts serving divination purposes enabled the user to get to know the date of their death, or they promised forgiveness for as long as several years (LoNDOÑ 2014:685). In ars notoria, there are no demons or damaging and self-serving purposes. The texts often emphasise the importance of the physical and spiritual purification of the user. Due to this, their medieval users could rest assured that their activity pleased God (LÁNG 2007:111). Probably in connection with this function, Ciruelo emphasises in his $16^{\text {th }}$-century Confession Mirror that this "practice or offshoot entices man with the promise that he learns all arts and sciences of the world within a short time, as long as he fasts and prays in the given day and hour (...)", "behind which may be nothing else but the manoeuvrings of the evil soul". Ciruelo warns that paying too much attention to mundane things is a sin in itself. ${ }^{16}$

In 1559, a few years after the publication of Ciruelo's Confession Mirror, Saint Cyprian's prayer appeared on the index - the list of banned Spanish texts - as an expressly prohibited prayer, and it was listed as well by a Portuguese index as non-desirable in 1561 (LONDOÑO 2014:685).

14 "las vanas cerimonias que muchas personas simples por indiscreta deuocion hazen diziendo algu[n] as oraciones que de si parescen sanctas, y buenas mas dichas con las tales obserua[n]cias vanas son peruersas" (CIRUelo 1544:42).

15 "que limitan ciertos días, y horas y vezes en que se ha de dezir alguna oracion: prometiendo que guardadas aquellas cerimonias se alca[n]çaran tales o tales gracias de nuestro señor" (CIRUELO 1544:43).

16 "arte o desco[n]cierto promete en breue espacio de tie[m]po alcançar el hombre a saber todas las artes y sciéncias del mundo: haziendo ciertos ayunos, y oraciones en determinados dias y horas" "no puede ser sino infusion del spiritu maligno." (CIRUELO 1544:43). [practice or offshoot entices man with the promise that he learns all arts and sciences of the world within a short time, as long as he fasts and prays in certain days and hours, (...) behind which may be nothing else but inspiration of the evil soul, [and it is a sin to put] too much desire in the goods of earthly world.] 


\section{CYPRIAN, THE MAGIC(IAN) SAINT}

What do we know about Saint Cyprian, to whom people of the Iberian Peninsula addressed their prohibited prayers in the Early Modern period? His much-debated life story includes magical elements itself. Thus, it is no coincidence that he played an ambivalent role in folk piety for centuries, and his judgment by the church generated a debate that also lasted for centuries.

Cyprian's prayer appearing in the mentioned indexes is not related to the bishop of Carthage, but to Saint Cyprian of Antioch, who lived at the turn of the $3^{\text {rd }}$ and $4^{\text {th }}$ centuries, working as a pagan magician before his conversion. ${ }^{17}$ His historical authenticity was long debated by hagiographers. Early sources remember him as the bishop of Antioch who died as a martyr. However, modern historians of the Western church even doubt his existence, and regard many of his life events as a part of folklore and apocryphal legends. In any case, the cult of Saint Cyprian bloomed among the believers of the Western church for centuries, and his figure was associated with functions of removing malefices.

According to apocryphal sources, Cyprian studied his profession in India and Egypt, and he became a renowned magician. He engaged in love magic, weather magic, divination, and necromancy, and, according to popular belief, he prepared love potions, used charms and magic spells, collected magical writings, and was able to create storm and rain, as well as to evoke the souls of the dead from the beyond. The apocryphal sources tell a story in which a young man came to Cyprian and asked him to help obtain a Christian virgin named Justina for a pagan youth. Cyprian evoked demons and sent them to attack her, but the girl stood up against them with the power of faith and the cross. Seeing that faith comes with an even greater power than demons, Cyprian converted to Christianity and burnt his magical books. He was baptised by bishop Anthimus and died as a martyr on 26 September 304, together with Justina, during the persecution of Christians under Roman emperor Diocletian. They were both tossed into a boiling cauldron, which they miraculously survived, and were eventually beheaded as martyrs. The legend of their lives exists in Latin, Greek, Syrian, and Ethiopian versions. ${ }^{18}$

Their reputation took a different course in the Western and the Eastern churches, and the sources related to them were treated rather differently. Their celebration days appeared in the calendar of the Roman Rite from the $13^{\text {th }}$ century until 1969 , when they were deleted because of the insufficiency of sources (See PAUL VI. 1991), and in 2001, their names were removed from the official list of martyrs of the Church of Rome as well. Their textual tradition, which evolved and survived for a long time, served too as a source for the Faust-legend.

The early hagiography of the saint was studied by Hippolyte Delehaye, who demonstrated the fatal philological mistake for which the Western church started to question the figure of Saint Cyprian, even doubting his historical authenticity and his very existence. Analysing the historical sources, Delehaye pointed out how the figure of Saint Cyprian of Antioch became contaminated with that of Saint Cyprian, the bishop of Carthage, shortly after his alleged martyrdom, from the $3^{\text {rd }} 4^{\text {th }}$ centuries on (Delehaye 1921).

17 There are also examples of confusing the two saints in the early sources.

18 Their tradition is still alive in the Orthodox Church: their intervention is requested against possession by devil and black magic. Further discussion of this issue is beyond the scope of the present paper. 
Saint Gregory of Nazianzus was the first Christian author among the early fathers of the church to merge the figures of the two saints into one in the $4^{\text {th }}$ century (379) in his sermon, Oratio in laudem sancti martyris Cypriani, which he probably delivered on 3 October 379 (D. Gregorii Nazienzi cognomento theologi opera omnia... 1. 1583:487494). Prudentius made the same mistake in Peristhephanon at the turn of the $4^{\text {th }}$ and $5^{\text {th }}$ centuries (Perist. XIII, 21-33) (LeONARDI et al. 2000:501), and it also occured in medieval sources. At the end of the $4^{\text {th }}$ century, Cyprian's legend was passed on in three different episodes. The manuscripts titled Conversio include the events after Cyprian's conversion, the Confessio carries the purpose of authentication, aiming to relate the real nature of the conversion - Cyprian tells in detail in first person singular how he became a magician - while Martirium tells how Cyprian and Justina were captured and beheaded. The three textual traditions were most probably linked in the early $5^{\text {th }}$ century (SowERS 2012:224). At this time, Aelia Eudocia, the wife of Byzantine emperor Theodosius II, wrote a poem about the life of this saint in hexameters.

As observed above, the development and reception of the legend was different in the Eastern and Western churches. In the $10^{\text {th }}$ century, Symeon the Metaphrast included certain events of the saint's life in his ten-volume Synaxarion written in Greek. Regarding Roman Christianity, Jacobus de Voragine included Cyprian's story together with Saint Justina in his Legenda Aurea in the $13^{\text {th }}$ century (1260-1267). ${ }^{19}$ Despite the fact that Justina's cult was proven to be blooming in Piacenza, Northern Italy, in the $9^{\text {th }}$ century, ${ }^{20}$ the story of the two saints, Cyprian and Justina, is only traceable with interruptions for long centuries.

Sources are missing especially after the $13^{\text {th }}$ century, and thus, there is no explanation yet for how Cyprian became a popular saint related to magical practices in Scandinavian and Iberian territories. Cyprian's figure played a significant role, especially in these two areas, in manuscripts and prints of the Early Modern period. His cult became part of the popular culture of the era, and he was well-known on the Iberian Peninsula in the $17^{\text {th }}$ century as well. There is evidence for this: Pedro Calderón de la Barca, Spanish poet and playwright, wrote a pious and cheerful play titled The Wonder-Working Magician (El mágico prodigioso) about the story of Saint Cyprian and Justina in 1637. In this work meant for entertainment, the theme of alliance with the devil is present already. The comedy was first performed in front of believers at the procession on the Lord's Day in Yepes. Based on this, the position and the attitude of the Church in connection with Cyprian has been ambivalent in the $16^{\text {th }}-17^{\text {th }}$ centuries. His prayer was forbidden already in the $16^{\text {th }}$ century; at the same time, the popularity of the saint was seen and respected, allowing his celebration. So popular this cult became that the loved and patronised playwright of Phillip IV received permission for a grandiose, festive show of the comedy popularising the saint, supposedly in front of an awed audience.

The church ban on the use of the prayer, however, was present throughout the $16^{\text {th }}-17^{\text {th }}$ centuries. It is important to consider, however, that "censorship did not mean a sharp line between permitted and prohibited; it was much more like a territory where heretical and 'orthodox' traits met, and public and private spheres were blended” (PeÑA Díaz 2015:17).

\footnotetext{
19 English translation: https://sourcebooks.fordham.edu/basis/goldenlegend/GoldenLegend-Volume5. asp\#Justina.

20 About its role in local liturgy in the Middle Ages, see MøLLER JENSEn 2012.
} 
Censorship is something that draws attention to the stubborn and widespread persistence of certain popular folklore practices.

Another important layer of the history of texts related to the saint, not discussed here in detail, consists of black books or grimoires, which spread in great numbers in French, Spanish, Portuguese, and Scandinavian territories in the Early Modern times. ${ }^{21}$ In Southern France, a belief existing at least from the late $15^{\text {th }}$ century affirmed that there was an existing magic book related to him (libro de San Cipriano, or ciprianillo), which contained various magical practices. In the $17^{\text {th }}$ century, several priests were summoned before the Saint Court in Galicia because they had used or copied the infamous Saint Cyprian book for treasure hunting, exorcism, and for saying several dubious coniurationes (conjurations). ${ }^{22}$ These trials deepened the popular belief that Saint Cyprian's book was kept safe and copied secretly in various monasteries. In these sources, the magic book is closely associated with sorcery, and its possession or application repeatedly appeared as a serious charge in the Inquisition trials of the Early Modern Period. ${ }^{23}$

21 According to an apocryphal legend, when Saint Cyprian converted with an honest heart, not all of his books were destroyed, but one of them survived, and has been circulated in copies up to the present days. There are several Cyprian books (ciprianillos) known in Portuguese, Spanish, and Scandinavian languages, all of which claim to be "the real one". Saint Cyprian of Antioch also appears in the works of the founder of theosophy, Helena Blavatsky. The cult related to the saint's character and, at the same time, the publication of the related texts revived in the $19^{\text {th }}$ century. (According to another related legend, the saint never stopped exercising his magical practices, but, after he converted to Christianity, he secretly used his magical knowledge to serve Christians.) The printed products used all kinds of authentication methods to be regarded as ancient Cyprian magic books. Probably the same happened to a $19^{\text {th }}$-century Latin magic book titled Cyprien Mago ante Conversionem, which dates "itself" back to 1460 (see SKInNER - RANKInE 2009:15). Owen Davies has not been able to trace any surviving copies of the referenced "book", and the author thinks that it might have been a local Bibliothèque bleue publication. See Davis 2009:115. Numerous Scandinavian manuscripts have been preserved as well: for example, a Norwegian manuscript from the $17^{\text {th }}$ century titled Cyrianus Konstbog (Cyprian's Art Book), which is a 33-sheet, 66-page source by an unknown author that can be found in the library of the University of Oslo (see OHRVIK 2012). Several grimoires including incantations, charms, and recipes in Norwegian are known, apparently written by Saint Cyprian. Most of these refer to a fictitious source from 1520 (or 1772), from Wittenberg, and there are several manuscripts in Danish from the same source as well. Their common trait is that they contain fortune- telling formulas, healing texts, recipes, and charms (for example, for protection against witches). According to these sources, Cyprian was a Dane, who lived on an island and had such an evil character that even the devil expelled him from hell and sent him home. Apparently, he wrote nine (!) books, full of charms. These were copied by a friar in three (or nine) copies, and they were circulated all over Scandinavia. This explains why (Saint) Cyprian's figure is so important in the Norwegian charms. The author of the manuscript mentioned is certainly an educated person, thus not related to popular culture (ОНRviк 2012). Similar magical texts can also be found in Latin-America with Spanish-Portuguese conveyance.

22 For a few examples collected and summarised, see BARREIRo 1885. Facsimile edition: 2010, La Coruña.

${ }^{23}$ In spite of that, we have rather little information on the Early Modern manuscripts in Spanish, unlike the contemporary sources written in Danish or Norwegian. 


\section{EARLY MODERN VERSIONS OF SAINT CYPRIAN'S PRAYER IN THE IBERIAN PENINSULA}

The popularity of Saint Cyprian of Antioch on the Iberian Peninsula is supported by sources from as early as the late Renaissance and early Baroque periods. As we can rely primarily on printed sources from the Early Modern period, it seems obvious that the text could have spread among the emerging bourgeoisie and the literate lower social groups. At that time, the prayer of Cyprian has probably been circulating in large numbers in vernacular language(s) in printed form in Italy and on the Iberian Peninsula. From that time on, instead of the Cyprian grimoires well known from Scandinavia, the study was focused exclusively on Saint Cyprian's prayer, hoping that its philological contributions allow for a better understanding of the history of the saint's cult, as well as how the texts and motifs have been passing on for centuries.

As of that moment, we know four different versions of Saint Cyprian's prayer from the Early Modern Period through popular texts. ${ }^{24}$ The earliest version was found in Biblioteca Colombina (cca. 1512) (LoNDoÑo 2014:683-693), ${ }^{25}$ the library of Hernando Colón (son of Christopher Columbus). This undated, 10-page text written in vulgar language, titled La Oratione de Santo Cipriano Volgare, was preserved in a book with mixed content. The possessor's note on the last page proves that the owner bought it in Rome in October 1512, so the text itself must date from before then.

Chronologically, the second version was already written in Spanish, published and presented by Javier Itúrbide Díaz (Itúrbide DíAz 2010:333-345). Its title is Oración devotísima de San Cipriano (A very devotional prayer of (to) Saint Cyprian), and we have slightly more data about its use and origins. This prayer was published significantly later than the previous source, between 1631 and 1634, by Cristóbal Lasterra, a priest from Navarra, who also mentioned in the publication that he translated the text from Latin. ${ }^{26}$ When examining this translation, we have to consider a change in the aim of the publication: in the transition from one printed version to another, the text is modified just like its market accessibility, its target audience, and thus the context of possible readers and actual reading practices. The translator, priest Cristóbal Lasterra, came from an impoverished noble family and studied theology at the University of Salamanca. He worked in Navarra and became a commissar of the Inquisition. It is known that he published an 82-page book on storm dispelling and exorcism in Latin, Liber exorcismorum cum adversus tempestates et daemones, in 1631 in Pamplona. It is known

${ }_{24}$ The present study does not discuss the versions found in magic books, although the different editions of the grimoires titled Enchiridion Leonis Papae serenissimo imperatori Carolo Magno... include important versions as well. The topic of magic books is to be discussed in detail in a future study by us. The Mainz edition of the mentioned grimoire attributed to Pope Leo III from 1663 does not include Cyprian's prayer; however, the editions published in Rome in 1660 and in Ancona in 1667 do include it. The latter was written in Latin (see pages 142-153, Oratio Sancti Cypriani), and the former, in French (see pages 107-115, Oraison de Saint Cyprien); thus, the journey of the text needs further examination, and hopefully, more details are to be revealed in the future.

25 The content of the text is being mentioned without including the text itself. The source can be found in Biblioteca Colombina (Sevilla). BCA Capitular y Colomb. Sign: 14-1-10(21).

${ }_{26}$ His biography and works are known thanks to the research carried out by Javier Itúrbide Díaz. See ITÚRBIDE DÍAZ 2010. 
from the cover of the chapbook printed later, which included Saint Cyprian's prayer, that the prayer originally came from this ritual book written in Latin and which was intended for clerical use and translated into Spanish by Lasterra himself. Apart from the Latin ritual text, this exorcism manual included prayers as well, Saint Cyprian's being one of them (fol. 68). We may consider this Latin text as the third version of Saint Cyprian's prayer text, although it is only known by reference.

Despite being an active member of the local Inquisition, Lasterra did not take into consideration that before the manual on exorcism was published, Cyprian's prayer, which he translated, had been listed in several Indexes for over 70 years before the publication of the text. As a commissar of the Holy Inquisition, his tasks included the inspection of local religious practices, collecting information about believers, hearing witnesses in suspicious cases, implementing arrests, as well as regular checks (Compare: HeNningSEN 1988:41). Although a "guardian" of religious life, he enabled the popularisation and spread of the prohibited Cyprian prayer in vulgar language by publishing the text in the first half of the $17^{\text {th }}$ century. It is curious that despite multiple bans on the text, the prefect responsible for the diocese of Pamplona sanctioned the publication of the Latin-language manual. He justified this decision by saying that he found the book especially useful for priests (ITÚRBIDE DíAz 2010:341). Thus, it was originally meant for ritual, or at least clerical use.

Based on its content, the Saint Cyprian prayer was used in cases of persistent drought or weather conditions threatening the crops; the parts of the text related to fertility and giving birth are linked to this function. Although the Cyprian prayer chapbook taken from the exorcism manual and meant for mass distribution was printed in the workshop of Martín Labayen in 1632, around the time it was banned again by the church (Index Librorum prohibitorum et expurgatorum), there is an explanation for why it did not fall victim to censorship. The smart typographer cunningly took out the church permission from the Latin exorcism book titled Liber exorcismorum and published the prayer as a separate print (pliego de cordel) ${ }^{27}$ along with the permission (ITÚRBIDE DíAz 2010:339). Thus, the use and distribution of the text became possible among every social group. It will become obvious further on that the aim of the text is to include even the illiterate in the audience.

This same prayer text by Lasterra was brought to the qualificators of the Inquisition in 1634, and thus it was examined by priests of the Jesuit order, who gained a growing political and intellectual influence in the age of Baroque and Counter-Reformation. The text was thoroughly analysed by five Jesuit priests of the Imperial College of Madrid (Colegio Imperial de Madrid). On 22 December 1634, they unanimously declared that Saint Cyprian's prayer was unworthy of use for various reasons. The position stated that the text was swarming with anachronisms, inaccuracies, and "superstitious" details (e.g., mention of the devil, putting malefice on enemies, etc.). Moreover, due to several "insolences", it cannot be attributed to Saint Cyprian.

The fourth, once again Spanish-language version of Saint Cyprian's prayer was also published separately. It can be found in the Bibliotheque Nationale de France, and its title, similarly to the previous version, is Oración devotísima de san Cipriano (A very devote prayer of (to) Saint Cyprian). The date of publication is unknown. Regarding both

27 "Pliego de cordel" in Spanish is a specific channel for printing popular literature, not only a "separate print" but also a cheap booklet which circulates easily among the people. 
font and content, it is identical to Cristóbal Lasterra's version; they are philologically parallel. ${ }^{28}$ So far, we have been familiarized with four versions of the text: three in Romance languages and one in Latin.

\section{THE CATALAN VERSION FROM 1557}

The text presented here as the fifth version has not been published so far. In a chronological order, this is the second Saint Cyprian prayer written in a Romance language from the Early Modern period, and thus far the only typological parallel in Catalan.

The author of this article found the Catalan version of the prayer in the Barcelona City Archive, in the Inquisition trial materials of Hiacinto (Jacinto) García, a hermit from Benavente (in the Kingdom of León of the Crown of Castile) (AHCB 16/1C. XVIII-9). The trial materials include the correspondence of the Inquisition commissar of Solsona, a town in the contemporary Principality of Catalonia, with the inquisitor of the Barcelona Court, as well as the testimonies of the witnesses and various documents of the hermit. Among these, the present study discusses Saint Cyprian's prayer, which fits into the chronological order introduced above, the ownership, reading, and use of which had a fatal impact on the hermit's life. The print is outstanding in the sense that it is significantly smaller than the other known Cyprian prayers. It is hardly bigger than an open palm, allowing its owners to carry it easily with them. The tiny chapbook that turned yellow includes a woodcut depicting Saint Cyprian and was published in 1557 by the widow of a printer named Carles Amorós, together with other prayers.

The printer's will reveals that he was originally from the County of Provance (Llanas 2002), and that his family name was Bolós. In France, the larger centres of book printing that emerged in the first half of the $16^{\text {th }}$ century - Paris, Lyon, Rouen, Toulouse, Poitiers, Bordeaux and Troyes - had been consolidated by this time. In the middle of the $16^{\text {th }}$ century, there were press companies in around 50 towns, and the number rose relentlessly. Entrepreneurs and merchants dealing with commerce and publishing did not have such a strict control over the economic operation of the industry as they did after the religious wars. At the time, simple printer artisans could decide for themselves what was profitable and worth printing (DAVIES 2001:172). The above-mentioned printer from Provence, Carles Amorós, studied in France. He probably heard from French booksellers working in Barcelona that the city was an ideal place and a profitable market for a printer. Thus, he settled there as early as 1498 , and indeed, he had barely any competition. In 1505 , he bought printing equipment from a Girona boot maker and started to work with it independently. He opened his own workshop in the beating heart of the city, in Portaferrissa Street branching off the famous promenade La Rambla, and soon he owned the most important local printing house of the first half of the $16^{\text {th }}$ century. From the period between 1507 and 1548, ninety titles have been associated with his name to date. These products served the most diverse market needs: they included official publications, Catalan historical works, literary works, publications for pious practices, as well as various popular readings of the time. His publications also document the transition from Gothic to

${ }_{28} \mathrm{BnF}$ (Bibliothèque nationale de France) http://gallica.bnf.fr/ark:/12148/bpt6k851256q/f1.image (accessed October 10, 2017). 
Roman font style. His business success was guaranteed by small prints delivered in great numbers: cards, fans, and various engravings, that is, popular paper products published in large numbers, of which very few copies survived for posterity. The majority (52\%) of the works published by Carles Amorós were in Catalan, 33\% in Latin, and 15\% in Spanish. These numbers reflect the language use of the audience that he envisioned.

The printer got married three times. He returned to his homeland in 1549 as an old man, and this was his last journey. The publication of Saint Cyprian's prayer in Catalan proves that after his death, his widow took over his business and continued to publish print products in Barcelona. It is not known whether his widow decided to publish new texts or promoted the reprinting of old ones.

Since there is no known Catalan text parallel to the examined Saint Cyprian prayer, and, considering the Early Modern versions of the text, it can be regarded as an early source. The author of this paper hereby publishes the transcript of the text ${ }^{29}$ and its English translation. ${ }^{30}$

\section{"La oració}

de Sant Cebria, y lo Euangeli de Sanct Joan, y los setanta dos noms de la verge Maria, y los set versos de Sanct Bernat, y lo Psalm Quicunque Vult.

[1v] Com Cebria fonch conuertit a nostre Senyor Deus e fonch be instruit e informat en la sancta fe catholica e sabent en les sanctes escriptures y en la sancta theologia, e molt inflamat en la amor e caritat de nostre senyor deu Iesu Christ y del prohisme: y Cebria pensant en la malicia y enueia del diable, y en los grans maleficis que fan los mals homens e males dones los quals son membres del diable, e ab los arts turmenten e vexen los seruents de deu en diuerses maneras: de manera que sabent fent Cebria [2] los grans maleficis que·s fan vuy en dia ordena aquesta oracio la qual deu esser dita per tres diumenges, e cada diumenge tres vegades. E te tal virtut que tota persona qui la portara ab si ab bona deucio, ho la legira ho la fara legir iames del dimoni sobrat sera, ni enemichs no li poran fer mal. E si alguna dona pregarya [sic! 'prenyada'] la aporta ab si sia certa que nose affollara mijancat aquestes sanctes paraules y si va de part, e la facia legir o que la tingua en son poder tantost sera desliurada, e la creatur['a'] no sera sorda,

29 The author would like to express her gratitude to Kálmán Faluba, Carles Bartual, and Josep Porredon for reviewing the transcript. When transcribing the print, the leading principles have been consistency and comprehensibility, at the same time striving for philological authenticity. For the sake of clarity, originally abbreviated words have been completed during the transcription. The word "que" is used in the case of the conventional abbreviation "q", and "sanct" in the case of "s". In case of incorrect spelling, the correct word form in square brackets is used. The page numbers of the printed booklet are indicated in square brackets in the body of the text. No line breaks have been applied. Word stress is not indicated; instead, the solutions of the source text are used. In case of proper nouns, however, initial letters are capitalized. In order to make comprehension easier, shortened adverbs sticking to verbs are marked with an apostrophe. For the same purpose, punctuation at the end of the sentences has been added. The present study only includes the first text from the small sized print published in 1557 , since its basic aim is to present the historical and social use and context of that text. The issue of intertextual relationships among the texts included in the print is not discussed.

30 For the sake of clarity, it is appropiate to publish the English translation of this Catalan prayer. The guiding principles of the English translation were clarity and comprehensibility, but in most cases the sentence lengths were not changed. The author highly appreciates all the remarks, suggestions and comments made by María Inés Palleiro. 
ni muda, ni contreta, ni lunatica ni endemo[2v]niada, e val contra totes metzines e fetilleries, factures y encantaments.

Oratio

En nom del pare e del fill e del sanct esperit. Amen. Io Cebria seruent de nostre senyor Iesuchrist posi lo meu seny e la mia memoria al alt e sobira e loable Deu omnipotent veent la mia maliciae los mals arts los quals lo de primer fehia enuia sobre mi la potestat del diable, empero ab lo seu nom me defensaua' e per lo meu gran peccat no plouia, ni la terra no donaua son fruy['t'] e les dones prenyades se affollauen, e los peixos coses de nadar y axi totes les coses de la mia [3] malicia eren ligades e per-so ara Deu meu prech te molt per la tua sancta dilectio que rompes los nuus e tos los ligaments y enuia pluía sobre la terra, e tots los arbres donen lur fruit e los peixos de la mar sien desligats, e totes les coses que son en ella e nengun mal esperit e[n] ells no puga aturar, ni en aquells ho en aquelles que aquest scrita portaran ho legiran, ho legir faran sien desliurats de tot mal, e profiten lurs persones e los lurs pensaments e los lurs fets i ferms en tot be, e tu senyor los vulles desliurar del poder del diable, e dels seus aguayts, e asso per lo teu sant nom [3v]glorificat en lo cel y en la terra, aquesta oracio fonch senyada per tu Emanuel que es Deu lo Pare e Fill e Sanct Esprit sies tostems ab mi seruent teu. Y placiet posar la tua Sancta Madre a sobre aquell home ho aquella dona que la aportara ho la legira ho la fara legir, ho la tindra en la casa sua ho en los seus bens. E mes te prech senyor Iesuchrist que formares Adam en paradis terrenal en lo comensament del mon, e feres en terra lo gran flum del qual hixen los quatre rius, Grison, Erison, Tygris, Eufrates, dels quals tot lo mon se rega, e restaurares a mi del diable maligne que [4] nengun mal esprit ni mala cosa no pugan contra aquesta teu seruent ni en nenguna de les coses sues noure ni enemics visibles o invisibles no li pugan noure o fer dany, o tu senyor, ver Deu lo vulles defensar e guardar de tot mal, e per la tua sancta virtut molt alt Deu, sien salues totes les coses sues, e la sua persona sia bona e tot los membres seus de la sobirana part del cap fis als pe['us'] dis e de fora de aquest seruent sien sancts e drets e sens lesio tots los sancts angels benys [sic!] que son dels nou ordens anomentas Seraphins, Cherubis, Trons dominacions principats ['principals'] potestats [4v] virtuts angels, archangels sien en la sua ajuda guarda y defensio, y placia a tu senyor desliurar e absolre lo teu seruent e les coses sues per les oracios dels angels mille milia miliu, que son dits versos que tot lo mon de tots los aguayts e tentacions del diable, lo qual no li puga noure en nengun loch ahon sia fet algun ligament ho actura ni blasfemia no li puga noure per la oracio de nostre Senyor Deu Iesuchrist e la pregaria de tots los sancts, e per la oratio de totes les sanctes, e per la humilitat dels pelegrins e per la bondat de Adam, e per lo teu angel del sacrifici de Abel e per la [5] castedad de Ioseph, e per la bondat de Rachel, e per la fe de Adam e per ligament de Ysach que tu Senyor restaurares, e per la obediensa de Melchisedech, per la dilectio e humilitat de Moyses, e per la oratio e glorificacio de Zacharies propheta, e per la mantinensa de Ieremies, e per los prophetes que no dormen abans lohen a tu, Senyor continuament e per la altitut dels cels, e humilitat de la mar fundable, e per los fundaments dels abissos e per les sanctes reuelacions e per les lengues dels sancts quatre euaugelistes ['evangelistes'] que ells me ajuden, e per la veu dels angels, e per los sermons dels sancts apo[5v]stols, e per aquells que vee lo propheta Moyses, e per la resplandor de les luminaries, e per tots los seruents dels teus sancts, e per la tua sancta natiuitat, e per lo teu sanct baptisme, e per la sanctissima veu que fonch cantada sobre tu dient "Aquest es lo meu fill amat, e molt me plau que tota la gent lo temen" e prech-te per aquells sinch milla homens que sadollares en lo desert, e per tu, Senyor Iesuchrist que feres de la aygua vi, e resuscitares a Lazar del moniment. E feres trespassament en la mar e feres lo vent cessar, e 
anares ab los teus amichs sobre la aygua, fores crucificat e soterrat e [6] resuscitat al tercer dia, e per la marauellosa ascensio tua per la tramesa del espirit per la consolacio dels pelegrins, e per tots aquells que amen a tu, Senyor sien destruydes totes les sacios e tots els ligaments los quals son ho seran fets contra aquest seruent teu ho en sos bens, ho en les coses sues. E tu, Senyor los volles defensar per la present oracio sancta e per les virtuts que aci he escrites jo, Cebria per lo manament de Iesuchrist que feres totes les coses, e per les sanctes paraules que tu, Senyor digueres en la creu com prengueres mort cruelment per saluar lo humanal linatge. Prech-te que et placie que si alguna [6v] factura o aligadura es feta en or ho en argent ho en altra cosa, en la persona de aquest seruent teu no li puga noure ni fer dany, e si alguna dona la legira ho la fara legir ho la tendra en casa sua ho sobre si la aportara en camp ho en casa ahon aquesta oracio sera sien tots los ligamens destruits que li sien fets per les sanctes virtuts damunt dites per algun christia ho lech ho saxarahi o altra persona no li puguen noure ni fer mal ni enemichs visibles ho inuisibles en totes maneres sien salues e los dits ligaments sien absolts per tu senyor omnipotent. E per lo sanct nom teu lohat e glorificat: ho en pe[7]dres ho en aygua ho en riu ho en mar ho en cor de ocells ho de animals ho de peixos ho en cabells ho en sus ho en jus, en camp, ho en vinya ho en arbre ho en lumaner ho en carrera ho fora carrera ho en altre loch. En acer ho en metal ho en vidre ho en qualseuol altra cosa que sien fetes aquestes ligadures ho factures de tot sien absoltes e desfetes que no puguen fer dany en aquest seruent teu, ni en los bens seus ho en les coses bones, ni mals esperits ni mals homens, ni males dones, ni enemichs visibles o inuisibles, ni nengunes males coses no li pugen noure, ni fer dany en la anima, [7v] ni en lo cos, ni a bens seus, ni en la sua casa de aquest seruent teu, e sia desliurat e absolt de males obres per virtut de aquesta sancta oracio, e per los teus sancts noms glorificats de Deu Abraham, de Deu Isach, de Deu Iacob, e tu, Senyor dona-li la tua dilectio y conserue'l en aquella per los noms de sanct Miquel, sanct Gabriel e sanct Raphael. E per totes les nou ordes dels angels. E per tots los prophetes, Ieremies, Dauid, Isayes, Daniel, Micheas, Ezechies. E per tots los sancts patriarches, Abraham, Isac e Iacob. E per los dotze Apostols sanct Pere, sanct Pau, sanct Andre, sanct Thomas, sanct Jaume, sanct Phelip, [8] sanct Bartholmeu, sanct Jaume, sanct Joan, sanct Simon. E per los quatre euangelistes Marc, Matheu, Luc e Ioan, e per les oracions dels angels beneyts e per tots los martyrs sancts, sanct Esteue, sanct Lorens, sanct Vincent e per los sancts confessors, sanct Syluestre, sanct Dionis ab los companyons sanct Marti, e per los doctors e sancts Sanct Agosti, Sanct Ambros, Sanct Hieronym, e per la corona de les vergens, sancta Maria, sancta Tecla, Sancta Eulalia, sancta Catharina, e totes les vergens que sonen la gloria de Paradis deuant tu, Senyor. E per lo sacrifici lo qual tu senyor feres pera saluar lo humanal linatge, e per los sancts noms [8v] per les sanctes oracions que son en lo libre Missat [sic!] sia absolt e desligat aquest teu seruent e tots be[' $n$ '] seus de tota mala vista e ligadura de tots los aguayts e tentacions del maligne esprit, e de tots sus ennemichs visibles ho inuisibles, e per lo sant nom de tu, Senyor Deu, lo Pare e Fill e Sanct Sprit. Io, Cebria de part de nostre Senyor Deu Iesuchrist e per la virtut que no te comensament ni tendra fin, e per la tua maiestat virtuosa expellesch lo mal esperit e totes males persones en nenguna manera no hagen poder en loch ahon aquesta oracio sia posada, e sia absolt nengun no'l puga noure, e sia[9] guardat de aquel axi com los tres infants, Sidrach, Misach e Abdenago, que no li puguen fer nengun mal en la casa, ni nengun mal aduersari, no'l puga noure, e tu, Senyor los defen per les plegaries damunt dites e vingua sobre lo esperit maligne tanta de maldictio que tu, Senyor lo destruesques e 1 metes en tenebres' y de aqui a dauant estiga que no fassa mal per la veu que fonc oida en lo mont de Sinay que fonch illuminat per la tua sancta claror e per la sancta hostia que lo preuere consagra en la Sancta Esglesia e per la tua preciosa sanch que tu, Senyor 
escampares que tots $[9 \mathrm{v}]$ aquells que aquesta sancta oracio tendran, sien guardats de tots periles infinita secula seculorum, Amen."

[The prayer of Saint Cyprian, and the Gospel of Saint John, and the seventy-two names of Virgin Mary, and the seven verses of Saint Bernard, and the Psalm Quicunque Vult.

[1v] As Cyprian was converted to our Lord God and became well instructed and informed in holy Catholic faith and knowledgeable in the holy scriptures as well as in holy theology, burning in holy fire with love and benevolence towards our Lord God Jesus Christ and towards his brothers in Christ: and since Cyprian was aware of the malice, and envy of the devil, and the great malefices put on others by bad men and women who are fellows of the devil and with evil deeds torment and pester the servants of God in different ways; Saint Cyprian, knowing [2] the great malefices that are used today, orders this prayer to be said through three Sundays, and three times each Sunday. And it has such a virtue that all the people who carry it with good devotion, or read it or have it read, will never be defeated by the devil, nor the enemies can harm them. And if a pregnant woman takes it with her, with the help of these holy words she can be sure that she will not miscarry, and if she goes into labour, and has this read to her or has it in her possession, as soon as she delivers her child, the creature will not be deaf, dumb, paralytic, lunatic, or possessed; the prayer is also effective against all poisons and sorcery, malefices and enchantments.

\section{Prayer}

In the name of the Father, Son, and Holy Spirit. Amen. I, Cyprian, servant of our Lord Jesus Christ, put my sense and my humble self in front of the high and sovereign and praiseworthy God Almighty, (who), seeing my malice, as well as the evil deeds that I used to do, sent the power of the devil upon me but with his name defended me; and because of my great sin, it did not rain, nor did the earth bear fruit; and pregnant women miscarried, and fish and swimming beings and thus, all the beings of my [3] malice were bound, and that is why now, my God, I beg you for your holy love that you break the clouds and all the bonds and send rain on the earth, so that all the trees bear fruit and the fish of the sea are liberated together with all the beings that are placed in the sea, and that no evil spirit can dwell in them, nor in those men or women who carry this writing with them or read it or have (somebody) read it; may they be free from all evil and may their persons, their thoughts and their deeds and firmness benefit from all good, and you, Lord, free them from the power of the devil and its ambushes; and this, by your holy name [3v] praised in heaven and on earth, this prayer was taught by you, Immanuel that is God, Father, Son and Holy Spirit, may you be with me, your servant, all the time. And if it pleases you, place your Holy Mother over that man or that woman who carries it with them or reads it or has (somebody) read it, or keeps it in their house or within their goods. And besides, I ask you, Lord Jesus Christ, who created Adam in the earthly paradise at the beginning of the world, and created the great flow (of water) on Earth from which the four rivers Pishon, Gihon, Tigris, and Euphrates were born, from which the whole world gains water: save me from the malevolent devil and that [4] no evil spirit or bad thing can harm this servant of yours or any of his things, nor visible or invisible enemies can harm him or do harm to him, and you Lord, veritable God, defend him and keep him from all evil, and by your holy virtue, the highest God, may all his things be saved and his person be good, and may all parts of this servant, from the upper part of the head to the feet, inside and outside, be holy and right and without injury; and all the good holy angels of the nine orders named Seraphim, Cherubim, Thrones, Principalities, Dominions, Powers, Virtues, and Archangels help, guard and 
defend him; and if it pleases you, Lord, to liberate and release your servant and his belongings by the prayers of the angels mille millia millium, which are the verses said in order that all the ambushes and temptations of the devil which are on earth cannot harm him in any place where they are used used to be some bond or machination, nor any blasphemy made can harm him, by means of the prayer of our Lord God Jesus Christ and the prayer of all saints; and by the prayer of all the saints, and by the humility of the pilgrims and by the goodness of Adam, and by your angel of Abel's sacrifice and by the chastity of Joseph, and by the goodness of Rachel, and by the faith of Adam and by Isaac's bonds that you, Lord, restored, and by Melchisedech's obedience, by the affection and humility of Moses, and by the prayer and glorification of the prophet Zechariah, and by the persistence of Jeremiah, and by the prophets who do not sleep but praise you, Lord, continually, and by the height of the heavens and the humility of the seabed and by the bases of the abysses and by the holy revelations and by the tongues of the four holy evangelists, may they help me, and by the voice of the angels, and by the sermons of the holy apostles, and by those seen by the prophet Moses, and by the brightness of the lights, and by all the servants of your saints, and by your Holy nativity, and by your holy baptism, and by the most holy voice that sang above you saying "This is my beloved son, with whom I am well pleased, whom all people fear", and I beg you for those five thousand men that you satiated in the desert, and for you, Lord Jesus Christ, who turned water into wine, and raised Lazarus from the dead. And you crossed the sea and stopped the wind, and walked with your friends on the water, you were crucified and buried and [6] resurrected on the third day, and by your miraculous ascension, by the sending of the Holy Spirit, by the consolation of the pilgrims, and by all those who love you, Lord, may all the machinations which are or will be done against this servant of yours or in his goods or to his belongings, and may all the bonds be destroyed. And you, Lord, defend them by the present holy prayer and by the virtues that have been written here by me, Cyprian, by the commandment of Jesus Christ who created all things, and by the holy words that you, Lord, said on the cross when you died in a cruel way to save the human genealogy. I beg you if it pleases you that if any [6v] machination or bond is made of gold or silver or something else, it cannot harm the person of this servant of yours, and if any woman reads this prayer or has it read or keeps it in her house, or takes it with her to the field or home, wherever this prayer could be, may all the bonds that were made by some Christian or lay or Saharan or another person be destroyed by the holy virtues said above, neither visible nor invisible enemies can harm him or do harm to him, they will be saved in every way, and said bonds will be released by you, omnipotent Lord. And by your holy name praised and glorified: either in [7] stones, or in water or in the river or in the sea, or in the choir of birds, or of animals, or of fish or in the hairs, above or below, in the countryside, in the vineyard or on a tree, or in a lamp or on the road or outside the road or elsewhere. Whether should them be made of metal or glass or any other thing from which these bonds or spells are made, may them be dissolved and undone, so that they cannot harm this servant of yours, nor to his property, goods and belongings, neither bad spirits nor bad men, nor bad women, nor visible or invisible enemies, nor any bad thing can harm him, nor harm him in the soul, [7v] neither in the body, nor in his goods, nor in the house of this servant of yours; and they may be freed and acquitted of evil deeds by virtue of this holy prayer, and by your holy glorified names of God Abraham, of God Isaac, of God Jacob, and you, Lord, give them your holy love and keep them in it by the names of Saint Michael, Saint Gabriel, and Saint Raphael.

And by all nine orders of the angels. And by all the prophets, Jeremiah, David, Isaiah, Daniel, Micah, Ezekiel. And by all the patriarch saints, Abraham, Isaac, and Jacob. And by the twelve Apostles, Saint Peter, Saint Paul, Saint Andrew, Saint Thomas, Saint James, Saint Philip, [8] 
Saint Bartholomew, Saint James, Saint John, Saint Simon. And by the four evangelists, Mark, Matthew, Luke, and John, and by the prayers of the blessed angels and by all the holy martyrs, Saint Stephen, Saint Lawrence, Saint Vincent, and by the saint Confessors, Saint Sylvester, Saint Dionysius and all his companions, by Saint Martin, and by the doctors and saints, Saint Augustine, Saint Ambrose, Saint Jerome, and by the crown of the virgins, Saint Mary, Saint Thecla, Saint Eulalia, Saint Catherine, and all the virgins that sound the glory of Paradise before You, Lord. And by the sacrifice that you, Lord, made to save humanity, and by the holy names, $[8 \mathrm{v}]$ by the holy prayers that are in the book of the Mass, this servant of yours and all his goods will be acquitted and released from all evil eyes and bonds, from all the ambushes and temptations of the evil spirit, and from all their visible and invisible enemies, and by your holy name, Lord God, Father and Son and Holy Spirit. I, Cyprian, on behalf of our Lord God Jesus Christ and by virtue that will not start or end, and by your virtuous majesty I expel the evil spirit, and no bad people will have power in any way wherever this prayer is placed, and [they shall] be acquitted, that no one can harm them, and be [9] saved from that, like the three infants, Shadrach, Meshach, and Abednego, who cannot suffer any harm in the house, nor any evil enemy can harm them, and you, Lord, defend them by the prayers said above, and so many maledictions will come upon the evil spirit that may you, Lord, destroy it and put it in the darkness and from now on it will be there so that it does not do any evil; by the voice that was heard in the Mount Sinai that was enlightened by your holy clarity and by the holy host that the priest consecrates in the Holy Church and by your precious blood that you, Lord, shed for all $[9 \mathrm{v}]$ those who have this holy prayer, may they be saved from all dangers forever and ever, Amen.]

In terms of content, the text is identical to the four Saint Cyprian prayers ${ }^{31}$ introduced above (Compare: LonDOÑo 2014:690). Thematic-motivic as well as narrative units of the Early Modern Cyprian prayer type are introduced below based on the Catalan version published here. The logic of segmentation is provided by the arrangement of the text units bearing different magical-religious functions. ${ }^{32}$

1. Contrastive conversion story. Recognition of God's benevolence in contrast with the malignancy of the devil as responsible for human suffering. The heading is directly followed by an apocryphal legend. The contrastive conversion story of the former magician: Cyprian - now a good Catholic - recalls his life and his harmful magical activities before the conversion. The saint (Saint Cyprian) admits that the devil has been the source of all troubles up to this day, and his fellows pester men and women in various harmful ways.

2. Use. The metalinguistic part referring to the use and effects of the prayer stands out from the text. According to this part, it must be said performed three times on three Sundays - like a novena. It is made clear that the text can be used as an amulet: literacy is not important, since the power of the text lays in the fact that it works if one reads it out or simply carries it with them. This part makes obvious that the text is meant for a broad

31 The present approach does not engage in genre issues, as that would lead far beyond the scope of the study. Based on the heading, the text is named "prayer", although there can be found connections with other genres as well.

32 Dániel Bárth wrote a comprehensive study on the similar purpose, thorough examination, and research history of Hungarian language peasant charms, church benedictions, and exorcisms. He himself introduced permanent and compulsory elements of benediction ceremonies, their structure, and the related liturgical text types, in comparison with peasant charms (BÁRTH 2010:91-100). 
audience. The possibility of using the text as an amulet, as well as reference to the magical power of the written text, appears several times. The amulet function also explains why Carles Amorós' version was so tiny. It is important to note that its format is not related to the ban on the text, since the first formal Index was delivered by the Roman Inquisition in 1559 , two years after the chapbook was published. Its size probably enabled its users to carry it with them, or to keep it at home, close at hand, in case of any individual crisis. It also turns out from this part that the main purpose of the text is removing malefice and helping women in giving birth (if the text is read out or the woman keeps it close when giving birth, the newborn will not be deaf, mute, lunatic, or possessed by the devil). It is also recommended for stopping droughts, or against the evil eye, charms, any kind of malefice, and visible or invisible enemies. (The identification of the users in the different versions may have varied based on current individual-historical crises; for example, its efficiency against plague and bad air, not mentioned in this Catalan version, is present in parallel texts.)

3. Making the sign of the cross. The actual prayer starts at the third text unit (Oratio, $[2 \mathrm{v}]$ ), with a part referring to the ritual gesture of making the sign of the cross. This strengthens the effect of the Cyprian prayer as a blessing action.

4. Presenting the actual situation of shortage. Cyprian prays to God in first person singular, admitting that the current state of drought or infertility is due to his own sins; there are no crops, and women giving birth have difficulties: all of this is caused by some kind of a bond or malefice.

5. Invocation and use. In order to solve the situation of shortage, Cyprian asks God or Jesus to dissolve the bond, to dispell all evil, and free the person from the power and manipulations of the devil. He asks as well for Mary's protection over the person carrying the prayer with them, reading it out or having it read out, or keeping it at home.

6. Invocation. Further request for protection by God or angels against visible and invisible enemies, as well as praise of God and his deeds, so that no bond or verbal harm can affect the person.

7. Listing the powers of the malefice-removing effect. The text first mentions the power of the Lord's Prayer and other prayers, then lists Biblical characters and their typical features. The function of the long list of phrases is intensification, by which evil forces are deterred. This narrative tool boosts the effectiveness of the text and the power of the rite. After that, the power of Jesus' miracles is discussed (referring to the wine miracle at the Marriage at Cana and the raising of Lazarus), which are analogous images of prosperity after deprivation. This narrative segment may be seen as connected to textual elements of a certain type of church ceremony order, where the exorcist priest supports his power by invoking the names, attributes, and Biblical deeds of God. ${ }^{33}$

8. Request and invocation. A repeated request is added for the dissolution of the bond, and an invocation to God, who saved humanity through dying on the cross; this time asking for protection with the power of Saint Cyprian's prayer.

9. The topography of the malefice. (Asking for protection against visible and invisible enemies for the person using the malefice.) The previous part is complemented by the listing of the topography, nature, and possible localisation of the malefice, which may be related to the magical belief saying one has power over whatever one knows. The text

33 For more details on the topic, see BÁRTH 2010:97. 
also lists the possible material of the malefice, which can be gold, silver, etc. Then, after the insertion of the metatextual part, further materials are listed, such as rock, river water, sea, birds, animals, fish, etc. ${ }^{34}$ These topics are followed by the part of the text aimed at the dissolution of the bond, break, or malefice in body and soul.

10. The positive effect of the prayer and its consolidation. To achieve more rhetorical efficiency, this part is based on listing Biblical figures and angels. Phrasing the dissolution once again serves the same purpose. Besides, invocation of the deeds of God and Jesus, as well the names of saints, angels, archangels, and prophets appear in order to deter the evil entity (in case of exorcisms, the demon), carrying the malefice (Compare: BÁRTH 2016:245).

11. Making the sign of the cross.

12. Expelling the evil: exorcism part. After referring to the gesture of making the sign of the cross, Cyprian, in first person singular, with the power of Jesus and aided by godly virtue and dignity, expels the evil spirits and persons with the help of the prayer. It is mentioned here as well that the text functions as an amulet in the house where it is kept. Devastation avoids the users, just like in the story of Shadrach, Meshach, and Abednego in Daniel, who did not burn in the heated furnace (Daniel, chapter 3). Cyprian asks God to eliminate evil and put it into the depths of darkness, so that it cannot do harm again. The intensity of the effect is strengthened by various phrases and images expressing godly power and sanctity.

13. Clause, the amulet-like protection. This part affirms that everyone who carries this prayer with them should be protected from all dangers.

The exploration of the textual relations of the Saint Cyprian prayer to church benedictions and exorcisms documenting conveyance and reception belongs to the future. However, metadata of certain versions of the prayer type give a different shading to the moment when the layman specialists engage in healing and malefice-removing activities.

\section{MAGICAL READING METHODS. THE USE OF SAINT CYPRIAN'S PRAYER IN THE $17^{\text {TH }}$ CENTURY}

In the course of the local conflict, which widened in 1641 as a consequence of the use of the Catalan prayer introduced in the study, the church was able to strengthen its contemporary position against "superstitious" deeds and provides a demonstrative example related to tolerated and condemned or banned paraliturgical activities and texts. Here we introduce only the early phase of the source trial, the elements of which provide insight into the use and context of Saint Cyprian's prayer in the $17^{\text {th }}$ century. Below, the peculiar text using practices of the hermit Hiacinto (Jacinto) García are presented, along with the role he played in his community. ${ }^{35}$ His activities were mostly related to healing the residents of the town, and his name is first mentioned in the testimony of a local widow.

\footnotetext{
34 Here we may refer again to a certain type of ordos: i.e., texts for expelling demons, which sometimes provide a lengthy description of the possible places of the malefice. For an actual related example, see BÁRTH 2010:97.

35 He signed his testimonies as "Jacinto García", and therefore, the study hereafter uses this form of his name.
} 
On 25 or 26 July 1641 - on Saint James' or Saint Anne's Day - in the city of Solsona situated in the Principality of Catalonia, Elisabet Vilaginés, the widow of Antoni Vilaginés, visited the peasant Pedro Villaró, who was lying seriously ill in bed. Upon entering the house, she saw the hermit living in the Saint Bartholomew hermitage near the city standing next to the sick man with a book in his hands, reading out something. The 60-year-old Elisabet did not understand the text; ${ }^{36}$ she only understood that the hermit was talking about sorcerers (hechiceras), and she also remembers that he lit a candle and put out its flame in a bowl of water.

Elisabet Vilaginés was the first to testify in the case of the hermit on 28 December 1641. However, Joan Codina, a canon of Solsona, had already gained information about the activities of the hermit. As commissary of the Holy Court, he addressed the Inquisition court of Barcelona in a letter on 29 November 1641. His letter was received four days later by the assigned inquisitor, Domingo Abbad y Huerta, who had 20 years of practice in judging and had just reached the peak of his career. The letter gave word about a hermit of the Saint Bartholomew hermitage a quarter of a mile from the town of Solsona, who healed all kinds of "uneducated and plebeian persons" ${ }^{37}$ with a rather suspicious prayer. The canon had witnessed with his own eyes that this prayer of Saint Cyprian written in the vulgar language, i.e., not in Latin, could be found on the list of publications to be expurgated or corrected. He asked the hermit for the chapbook, but he refused to fulfil his rather emphatic request. Seeing the insolence and disobedience of Jacinto García, the canon used his means freely to obtain the print containing the prayer. The hermit claimed that he had lent it to somebody, who confirmed it, adding that they had afterwards burnt it without any permission or authority. As his behaviour only strengthened the suspicion against him, Joan Codina wished to search the hermit's "books", to make sure that he was not hiding anything that could prove dangerous to the Catholic faith. He also informed his Excellency that the hermit living in the hermitage on the high hill healed women and encouraged them to climb the steep road on several previously designated days in a row.

On December $8^{\text {th }}$, the canon composed another letter to the inquisitor, informing him that the hermit used candles and maybe holy water during healing, and at the same time recited one of the gospels and uttered superstitious words. In his reply, Domingo Abbad y Huerta gave Joan Codina clear orders to extensively interrogate everyone the hermit

36 In her testimony, Elisabet's age is indicated like that of every other witness in the time "approximately" 60 years. In the $17^{\text {th }}$ century, witnesses gave their age as they estimated it; this makes the said and written data merely an approximation, to be further specified based on birth certificates. In the case of Elisabet, her actual age was 54 in 1641. Based on the Solsona registry, she was baptised on $10^{\text {th }}$ September 1587 , her father was a peasant named Joan Olivelles, and her mother's name was Isabet. The child was baptised as Isabet (source: ADS, Parroquials, Solsona, s. n., 158). She first got married at the age of 21, on 24 November 1608, to a peasant called Pere Viladecamps (elsewhere: Viladecans) from Riner (Reiner), in the chapel of the Monastery of Our Lady in Solsona (Capella de Nostra Senyora de la Claustra) (Source: ADS, Parroquials, Solsona, s. n., 20v.). After her husband died, she was remarried in 1620 to a smith named Antoni Vilaginés, also a widower (source: ADS, Pia Unió, $n^{\circ}$ 95b). The present study uses the Catalan form of the names of local people, although the first part of the trial was written in Spanish - the official language of the contemporary administration. The author would like to express her gratitude to Josep Porredon, the knowledgeable expert of the Diocesan Archives of Solsona, for always providing effective and thorough help with the archives.

37 "Personas idiotas y de poco ser." 
had healed in such a way, and to inform him immediately should he learn anything else. Thus, more than a dozen persons involved testified about Saint Cyprian's prayer and the related healing practices of the hermit in Solsona in front of the canon, and later in front of the higher Inquisition authorities.

\section{THE HERMIT'S PATIENTS}

In the winter of 1641, the Holy Court officially turned its attention towards Jacinto García. In relation to his activities, fifteen witnesses appeared in front of commissary Codina by January $12^{\text {th }} 1642$. As eyewitnesses or persons concerned, they gave a most detailed account of how the hermit had healed their relatives or acquaintances. The witnesses had reason to be fearful: many of them only admitted after repeated questions that they knew why the canon had summoned them. Had they actively participated in any kind of superstitious deed, they could have easily got into trouble themselves. Joan Codina summoned one by one the town residents, who gave account of altogether six healing cases related to García during the secret hearings. Among these, the healing of plague, leg ache, a hand wound, and other, unnamed diseases were mentioned.

Although only a small number of people were questioned, it is worth asking what social layer could have turned to the hermit. The patients testifying were mostly peasants and artisans, with an especially high proportion of wool beaters.

The testimonies given by the witnesses varied in terms of detail, depending on who the actual patients were: the witnesses themselves, their relative or acquaintance, or if they had only heard about the activities of the hermit. One thing is for sure: it was not merely occasional aid. Even the local priests knew that the hermit was a well-known and acknowledged healer all around Solsona and even outside the town. More than half of the witnesses mentioned that the activity of Jacinto García was vox populi (es voz pública), and everyone knew that he healed with prayers and gospels.

According to the testimonies, he read out from a book, ${ }^{38}$ and what he read was Saint Cyprian's prayer and a gospel from the same print. Although he read it out (somewhat) loud, the patients did not understand the Latin and Spanish parts of the text. The mother tongue of García was Spanish, and we cannot know for sure how well he spoke Catalan or what his accent was like. The scribe wrote the records of the first phase of the trial in Spanish because of the contemporary centralisation of imperial procedures. However, the main reason of incomprehension by the testifiers might not have been the language barrier, since Cyprian's prayer was said in Catalan, the language primarily used among the people of the town. The explanation might be the ceremonial way of performing the text: not fully comprehensible and supposedly semi-loud reading, quiet speech, closed

\footnotetext{
38 It is worth mentioning here that reading out loud bears a considerable acoustic and motoric code as well. In the Early Modern period, the act of reading involved the sounding of phonemes at a certain volume, as well as vocality and the visible movement of muscles resembling chewing (DE CERTEAU 2000:188). This also relates to the Zumthorian idea that medieval written texts should be interpreted together with their contemporary vocality, that is to say, voice used to belong to the world of literacy like some sort of an acoustic performance. This statement also applies to the Early Modern period. See for example: ZumhtoR 1983.
} 
body posture, turning one's back to the people present, the numerous ritual tools, and the delivery that was hard to follow; since the patients were hardly able (or willing) to recall anything even from the content of the Catalan text. It might easily be the case that they did not want to mention longer textual elements, since it would have carried the risk of complicity. One of the parts they mentioned was when the witches bound the clouds. Binding the clouds and infertility due to drought is mentioned two times in the prayer text: on pages 2 and 3; first as a consequence of Cyprian's sins, and later as a prayer to God to dissolve the bond from the clouds. It is interesting that, according to certain testifiers, witches bind the clouds in the text. This idea is not present in Cyprian's prayer. Thus, mentioning witches in the testimonies means a locally adapted element of the content. The testifiers recalled no other parts of the text and connected the use of it exclusively to the hermit as a healing specialist.

\section{THE HEALING PRACTICES OF JACINTO GARCÍA}

Although we know from the witch trials that deeds attributed and practices actually carried out were not necessarily identical (Compare: BLÉCOURT 2008:297), the unanimous testimonies allow us to reconstruct a general scheme that may be regarded as an individual magical-ritual practice, which was probably applied by the hermit in case of various diseases with smaller or greater changes. What follows is an overview of the written and read texts and gestures that accompanied his healing activities, most of which were confirmed by the hermit himself in his testimony.

Some of his patients had to visit him through nine mornings with an empty stomach at the hermitage, where he carried out his healing rites. ${ }^{39}$ The patient had to kneel, and the hermit held a cross in his hand, worshipped by the patient. Meanwhile, García was reciting the Gospel of Saint John and Saint Cyprian's prayer, and lit a candle. ${ }^{40} \mathrm{He}$ kept (probably) holy water in a bowl, which he occasionally poured into his mouth and scattered it on the sick body part from there. He put out the candlelight in the bowl. He admitted to having also said three masses: one for Saint Sylvester, one for Saint Cyprian, and one for Saint Cecilia. In addition, during the nine days when he was curing the patients, he made a text amulet, a breverl (nómina or albaran in contemporary Spanish) for them, beginning with the words "Qui verbum caro factum est...". ${ }^{41}$ He placed a mixture of hemp-agrimony, rosemary, and rue in the breverl, and told the patients to carry it with them. The use of amulets bringing good luck and helping in recovery was clearly forbidden by Pedro Ciruelo's treatise on "superstitions" already in the $16^{\text {th }}$ century. Ciruelo's above-mentioned work was published again in 1628 in Barcelona, based on the permission and recommendation of the bishop of Solsona himself. The trial

39 At this point, let us recall the recommendation for use in the written text: "deu esser dita per tres diumenges, e cada diumenge tres vegades." [to be said on three Sundays, and three times on each Sunday.]

40 The excerpt from the Gospel of Saint John can also be found in the hermit's chapbook, directly following Saint Cyprian's prayer. "In principiū erat verbū..." [In the beginning it was the Word...] This text can be found in several exorcism manuals of the era. Father Rókus, the exorcist of Zombor, liked to use it as well. Compare: BÁRTH 2016:248.

41 "And the Word was made flesh..." (Literal from Latin: "That the Word..."). 
also documents that the local priests regarded the work as reference in religious cases in 1641 (Ciruelo 1628). One of them even lent Jacinto García the treatise published a few years before the case, so that he could learn from it and no longer go astray.

It is known that the hermit was literate. Considering the nature of his own healing rite, he probably knew the exorcism manual of Hieronimo Mengo (or Menghus/Girolamo Menghi), Flagellum daemonum, which was widely known, read, and used in Europe at the time (placed on index in 1709). The book saw several editions from the $16^{\text {th }}$ century on. The breverl beginning with the words Qui verbum caro factum est... can be found on page 374 of the 1584 edition and on page 207 of the 1604 edition, together with accurate instructions of use in Latin, including gestures and texts to be said in order to attain the purpose. The aim of the rite is to exorcise demons that pester people. ${ }^{42}$ Although this book was not found in the hermitage during the trial, there were a lot of other writings copied from books and manuscripts. Thus, no one knows the number of copies preceding the Latin text included in the trial documentation, copied with mistakes and words crossed out here and there - which is the breverl itself without the instructions.

What was García's primary sin? The justification of the church related to the healing was that the hermit did not have the permission of the church to do consecration or exorcism. Despite the position of the church, one might raise the question of why the patients turned to the hermit. It is especially interesting, because he was not the only option to go to in case of illnesses or any harm they suffered. Based on information from archival sources, the number of doctors, surgeons, and pharmacists was particularly high in Solsona and its surroundings in the $1600 \mathrm{~s}$, mostly thanks to the Pallerès dynasty (See, for example, Coromines I Balletbò 1994). In the first half of the $17^{\text {th }}$ century, and at the time of the trial, even a pharmacy operated in the town. Doctors, herbalists, priests, and pharmacists were easily accessible for the residents of the town, which was an episcopal centre. And yet, Jacinto García claimed in his testimony that the doctors had abandoned these patients.

One might get closer to the answer through contemporary popular thoughts about illnesses and troubles. The community enlisting the services of the hermit may have implicitly expected the same approach that also drove the idea of witchcraft for centuries. According to this, any internal or external trouble, that is, physical or mental illness, damages affecting the household, the economy, or the food structure, as well as bad weather, all emerge as a consequence of an evil spell. And behind these malefices were actual persons possessing wicked powers, together with their hostile feelings (envy, conflict). This idea is supported by the text of the prayer on the one hand, and, on the other, by the local pathology and popular diagnosis unfolding from the testimonies. Based on these, illness is created as a consequence of consuming a metzina (poison), which is sent into the household by a harmful person with some food (in the actual trial, a pot of rice and wine), as a consequence of envy. These harmful persons were mostly women who could be identified through divination. Thus, Jacinto García acted as an intermediary, a specialist coming from outside the local society, and he was ruined because he accused the above-mentioned Elisabet Vilaginés, an influential woman in

42 For example: "Deinde acsipe fal exorcizatum \& benedictum, cerum avei Pascualis, vel aliam benedictam \& rutam benedictam ropria benedictione positu supra folio 43 etc." Mengo (MenGHI) 1584:375, or "Adjurationes formidables, potentissmas, \& efficaces in malignos spiritus fugandos de oppressis corporibus humanis" Mengo (MeNGHI) 1727:298. 
clerical circles, of witchcraft. Or, maybe, she was accused by other people of the town (more than one), who transmitted this responsibility to the hermit in their testimonies, since he consequently denied that he would have said such things and named the community as the accuser.

Healing by Jacinto García could actually also work without the identification of the agent, and most of his remedies bear the marks of Catholicism: he used holy water, blessings, incense, and the rites of exorcism for natural and supernatural problems alike (Compare: BLÉCOURT 2008:298). He should have obtained the permission of the church for that, but he acted without it. Jeroni Bodies, a priest of the Solsona Cathedral, had known about it from the beginning, and he voiced his displeasure in one of his testimonies. He mentioned that the hermit dispelled storms without any kind of permission. ${ }^{43}$

The last section of the present paper provides a short overview of what we know about the life of the healing hermit. He mentions in his own testimony that he was born in Benavente around 1604. His father was a lawyer named Gaspar García, and his mother, María de Madrid. They both lived in Benavente, but the hermit had no closer information about them at the time of the trial. He had twelve siblings: ten brothers and two sisters, who both died before they could have got married. One of his brothers was the secretary of the Holy Court of Toledo. With regards to his origins, he claimed to be "clean": he was not a "born-again Christian", as all his direct and collateral relatives were "old Christians with an impeccable reputation and good life", not converts. None of them had ever stood in front of the Holy Court. He regularly confessed and took part in Communion, and the archbishop of Ovideo had celebrated his confirmation; and, just before giving his testimony, he had confessed and took part in Communion in the Saint Dominic Monastery in Balaguer, in the Principality of Catalonia. He could read and write but never attended the university.

So, the hermit stood in front of the court as a stranger from a distant place, but following the official religion: a defendant not threatening the integrity of the empire by his origins. He firmly stated that he had never held a conversation with anyone who would have been suspicious in terms of faith. At the age of 18, he left his home to do seasonal work (harvest) in Palencia, where he spent three months while serving in the Saint Augustine Monastery. Afterwards, he went to Aragonia, and, after a short stay there, arrived in Catalonia and started his activities in Solsona.

He had compiled his healing techniques on the basis of several readings. Apart from the prayer, the gospels, the exorcism text, and religious literature, he had also read a medical book, the title of which he did not remember, but he could recall that smoking certain herbs was good for getting rid of body fluids. He also used the tools of magical rituals in his method (fasting, using oil for healing, putting out a candlelight as an analogy of removing the harm), procedures that were mostly inspired by his readings. He regarded himself a humble Christian and made sure to include the defensive discourse of commitment to piety and healing in his testimony. As he said, "I did not do all of these to offend our God, our Lord, or our holy Catholic faith, but out of piety and a deep faith;

43 He was probably referring to the use of the Gospel of Saint John mentioned above, which at the time also served as a conjuration for keeping storms away. 
and if I could heal patients with the blood running in my veins, I would do so, rather than offending our holy Catholic faith - if not, may the black earth devour me". ${ }^{4}$

\section{FINAL CONSIDERATIONS}

We do not know how Jacinto García obtained that tiny chapbook published in 1557 that he used for healing in the first half of the $17^{\text {th }}$ century. He may have received or bought it during his many journeys in the Principality of Catalonia, and he might have used it in other towns as well, before he moved into the Saint Bartholomew hermitage near Solsona. The Inquisition did not ask him about that. The present study discussed four philological parallels of the printed text that he used and placed them in context with the help of contemporary sources and trial details.

Through his activities, we saw an Early Modern example for the personal, ritualmagical use of reading. Owning the text, he acted in the function of a specialist in an urban community, and he was not the only one on the plural health and medicine market. (See Sallés I Planas 2008.) He gained his knowledge from various sources, and he probably knew the ceremonial books of the era based on the Latin rite, as well as other popular readings that provided him with inspiration. According to his testimony, he was a reading-writing person. He did not remember the title of his books and readings; however, the nature of his manuscripts and notes provides an insight of his inner world. His peculiar fabrications made him authentic and attractive in the eyes of his patients for a while. The course his life took afterwards will be discussed in further writings by the author.

\section{REFERENCES CITED}

BARREIRO, Bernardo

2010 [1885] Brujos y astrólogos de la Inquisición de Galícia. Hechicería, oscurantismo, fanatismo religioso y el Santo Officio en la Galicia antigua [Warlocks and Astrologers of the Inquisition of Galícia. Sorcery, Obscurantism, Religious Fanaticism and the Holy Office in Ancient Galicia]. (1885. Facsimile edition: 2010) La Coruña: Extramuros Edición, S. L.

BÁRTH, Dániel

2010 Benedikció és exorcizmus a kora újkori Magyarországon [Benediction and Exorcism in Early Modern Hungary]. (Fontes Ethnologiae Hungaricae IX.) Budapest - Pécs: L'Harmattan - PTE Néprajz-Kulturális Antropológia Tanszék.

2016 A zombori ördögüzö. Egy 18. századi ferences mentalitása. [The Exorcist of Zombor. The Mentality of a Franciscan from the $18^{\text {th }}$ Century]. (Vallásantropológiai tanulmányok Közép-Kelet-Európából 3.) Budapest: Balassi Kiadó.

\footnotetext{
44 "y esto no lo hacia por ofenssa de Dios nuestro Señor, ni por offensa de nuestra Santa Fe Catholica, sino por más deuosión y mas fe y si con la sangre de sus venas les puediera sanar a los dichos enfermos, les sanara y que antes que este hiciesse cosa contra la Santa Fe Catholica, se quisiera ver consumido bajo muchos estrados de tierra."
} 
BLÉCOURT, Willem de

2008 Witch Doctors, Soothsayers and Priests. On Cunning Folk in European Historiography and Tradition. Social History 19(3):285-303.

CHARTIER, Roger

1992 Laborers and Voyagers: From the Text to the Reader. Diacritics 22(2):4961. https://www.sas.upenn.edu/ cavitch/pdf-library/Chartier_Labourers.pdf (accessed July 15, 2019)

2011a Lecturas y lectores "populares" desde el Renacimiento hasta la época clásica ["Popular" Readings and Readers from the Renaissance to the Classical Era]. In CAvallo, Guglielmo - Chartier, Roger et al. (eds.) Historia de la lectura en el mundo occidental, 335-351. México: Santillana Ediciones.

2011b Szövegek, nyomtatványok, olvasatok [Texts, Prints, Readings]. In DéRI, Balázs - Kelemen, Pál - Krupp, József - TAMÁs, Ábel (eds.) Metafilológia 1. Szöveg, variáns, kommentár. 162-178. (Keszeg Anna fordítása) Budapest: Ráció Kiadó.

CLARK, Stuart

1997 Thinking With Demons: The Idea of Witchcraft in Early Modern Europe. Oxford: Oxford University Press.

Coromines i Balletbò, Marcel

1994 Els Pallarès de Solsona (1450-1885). Tesi. Manuscript. (Solsona).

DAvIs, Natalie Zemon

1981 Printing and the People: Early Modern France. In HarveY, J. Graff (ed.) Literacy and Social Development in the West: A Reader. Cambridge: Cambridge University Press.

2001 A könyvnyomtatás és a nép [Printing and the People]. In DAvIs, Natalie Zemon: Társadalom és kultúra a kora újkori Franciaországban, 169-198. Budapest: Balassi Kiadó.

Davies, Owen

2009 Grimoires. A History of Magic Books. Oxford: Oxford University Press.

De Certeau, Michel

2000 La invención de lo cotidiano I. Artes de hacer [The Invention of Everyday Life I. The Art of Making]. México, D. F: Universidad Iberoamericana. (Newer edition of the first edition in Spanish.)

Delehaye, Hippolyte

1921 Cyprien d'Antioche et Cyprien Carthage. Analecta Bollandiana (39):314-332. GinzBurg, Carlo

1992 The Cheese and the Worms: The Cosmos of a Sixteenth-Century Miller. Baltimore: The John Hopkins University Press.

HeNNINGSEN, Gustav

1980 The Witches'Advocate: Basque Witchcraft and the Spanish Inquisition (16091614). Reno: University of Nevada Press.

1988 A boszorkányok ügyvédje. A baszk boszorkányság és a spanyol inkvizició (1609-1614). [The Witches' Advocate. Basque Witchcraft and the Spanish Inquisition]. Budapest: Kossuth. 
ITÚRBIDE DÍAz, Javier

2010 Piedad popular, exorcismos y censura inquisitorial. La Oración de San Cipriano impresa hacia 1631 [Popular Piety, Exorcisms and Inquisitorial Censorship. The Prayer of St. Cyprian Printed Around 1631]. Huarte de San Juan. Geografía e historia 17:333-345.

LÁNG, Benedek

2007 Mágia a középkorban [Magic in the Middle Ages]. Budapest: Typotex.

LEONARDI, Claudio - RicCARDI, Andrea - ZARRI, Gabriella (dir.)

2000 Diccionario de los santos Vol. I. (A-I) [Dictionary of Saints]. Madrid: San Pablo.

Llanas, Manuel

2002 Carles Amorós. http://lletra.uoc.edu/ca/edicio/carles-amoros (accessed August 5, 2019).

LONDOÑO, Marcela

2014 La condena de la oración supersticiosa en el siglo XV. El ejemplo de San Cipriano [The Condemnation of Superstitious Prayer in the $15^{\text {th }}$ Century. The Example of St. Cyprian]. In Esteve, Cesc (ed.) El texto infinito. Tradición y reescritura en la Edad Media y el Renacimiento, 683-694. Salamanca: SEMYR.

MARQUILHAS, Rita

1999 Orientación mágica del texto escrito [The Magical Orientation of the Written Text]. In Castillo Gómez, Antonio (comp.) Escribir y leer en el siglo de Cervantes, 111-128. Barcelona: Gedisa.

Møller Jensen, Brian

2012 The Story of Justina and Cyprian of Antioch as told in a Medieval Lectionary from Piacenza. Stockholm University. http://www.diva-portal.org/smash/get/ diva2:530217/fulltext01 (accessed November 5, 2017).

OHRVIK, Ane

2012 "For All Honest Christian and Science-Loving Readers..." Religious Encounters in Early Modern Norwegian Black Books. ARV. Nordic Yearbook

PAUL VI. of Folklore (68):7-26. Uppsala: The Royal Gustavus Adolphus Academy.

1991 Mysterii Paschalis motu proprio, 14 February 1969. In Római Misekönyv. Budapest: Szent István Társulat.

PEÑA Díaz, Manuel

2015 Escribir y prohibir. Inquisición y censura en los Siglos de Oro [Write and Prohibit. Inquisition and Censorship in the Golden Age]. Madrid: Cátedra.

PÉrez García, Rafael M.

2002 Del uso mágico de lo escrito en el siglo XVI [The Magical Use of Writing in the $16^{\text {th }}$ Century]. In Actas del III Congreso de historia de Andalucía, Córdoba 2011. Historia moderna (III) Separata, 251-266. Córdoba: Publicaciones Obra Social y Cultura Cajasur.

SALLÉS I PLANAS,Lluís

2008 Metges i cirugians més destacats a Solsona de 1565 a 1700 [Most Prominent Doctors and Surgeons in Solsona from 1565 to 1700]. Gimbernat 49:81-84. Not cited in the text. 
SKINNER, Stephen - RANkINE, David

2009 The Grimoire of Saint Cyprian. Clavis Inferni. The Golden Hoard Press.

SLuHovsky, Moshe

2007 Believe Not Every Spirit. Possession, Mysticism, \& Discernment in Early Modern Catholicism. Chicago \& London: The University of Chicago Press.

SOWERs, Brian

2012 Thecla Desexualized: The Saint Justina Legend and the Reception of the Christian Apochrypha in Late Antiquity. In Martin McDonald, Lee Charleswoth, James H.: "Non-Canonical” Religious Texts in Early Judaism and Early Christianity, 222-233. London: T\&T Clark.

TAusiet, María

1994 Religión, ciencia y superstición en Pedro Ciruelo y Martín de Castañega [Religion, Science and Superstition in Pedro Ciruelo and Martín de Castañega]. Revista de Historia Jerónimo Zurita (65-66):139-144.

2004 Pedro Ciruelo (1470-1548). In Golden, Richard M. (ed.) Encyclopedia of Witchcraft I. The Western Tradition, 191-192. Santa Barbara: ABC-CLIO.

THOMAs, Keith

1991 Religion and the Decline of Magic: Studies in Popular Beliefs in Sixteenthand Seventeenth-Century England. Oxford: Oxford University Press. [1971]

Voragine, Jacobus de

Legenda Aurea. The Golden Legend. English translation: https://sourcebooks. fordham.edu/basis/goldenlegend/GoldenLegend-Volume5.asp\#Justina. (accessed July 7, 2019).

ZuMTHOR, Paul

1983 Introduction à la poesie orale [Oral Poetry: An Introduction]. Paris: Seuil.

\section{EARLY MODERN PRINTS}

Ciruelo, Pedro

1538 Reprovación de las supersticiones y hechizerías. Alcalá de Henares.

1544 Co[n]fessionario. compuesto por el maestro Ciruelo. Es el arte de bien confessar muy prouechosa al confessor y al penitente; en el qual agora nueuamente añadidos muchos apuntamientos en muchos lugares. Impresso en Medina del Campo, en 1544 por Pedro de Castro. http://bvpb.mcu.es/es/ consulta/registro.cmd?id=439480 (accessed July 15, 2019)

1628 Tratado en el qual se reprvevan todas las svpersticiones y hechizerias: muy vtil y necessario a todos los buenos Christianos zelosos de su saluación. Compuesto por el Dotor y Maestro Pedro Ciruelo, Canonigo de la Santa Iglesia Cathedral de Salamanca... En Barcelona, por Sebastian Coromellas.

ENCHIRIDION

1660 Enchiridion Leonis Papae serenissimo imperatori Carlo Magno in munus pretiosum datum nuperrimé mendacis omnibus purgatum. Romae.

ENCHIRIDION

1667 Enchiridion Leonis Papae serenissimo imperatori Carlo Magno in munus pretiosum datum nuperrimé mendacis omnibus purgatum. Anconae. 
D. GREGORII NAZIENZENI

1583 D. Gregorii Nazienzeni cognomento theologi opera omnia quae extani, nunc primum porter novam plurimorum librorum. I. Parisiis.

Mengo, Hieronimo (Menghi, Girolamo)

1584 Flagellum daemonum. Exorcismos terribles potentissimos e efficace. Bononiae: Joannem Rossium.

1604 Flagellum daemonum. Exorcismos terribles potentissimos e efficace. Venetiis: Bertano.

1727 Fustis daemonum. Adivrationes formidables et potentissimas, ad malignos spiritos effugandos de oppressis corporibus humanis... Tomus tertius. Francoforti, Typus Wolffgangi Richteri, sumptibus heredum Nicolai Bassaei. $\mathrm{BNF}$ (Bibliothèque nationale de France) http:/gallica.bnf.fr/ark:/12148/ bpt6k851256q/f1.image (digitalised print)

\section{ARCHIVE SOURCES AND ABBREVIATIONS}

ADS Arxiu Diocesà de Solsona

AHCB Arxiu Històric de la Ciutat de Barcelona

Bernadett Smid is a senior lecturer at Eötvös Loránd University, Budapest. She graduated in Spanish Studies and Ethnography and acquired her PhD in 2011. Her PhD dissertation discussed Early Modern Spanish romances. She is especially interested in the historical relations of the oral and written traditions as well as in the aspirations of the church for female education. She currently conducts research about the Inquisition materials of the Principality of Catalonia of the $17^{\text {th }}$ century and the magical healing practices included in them, as well as in the related contemporary discourse of the church. E-mail: bernadett.smid@gmail.com

Open Access. This is an open-access article distributed under the terms of the Creative Commons Attribution 4.0 International License (https://creativecommons.org/licenses/by/4.0), which permits unrestricted use, distribution, and reproduction in any medium, provided the original author and source are credited, a link to the CC License is provided, and changes - if any - are indicated. (SID_1) 
